\title{
ПОЛИМОРФИЗМ ГЕНОВ ДОФАМИНОВОГО ТРАНСПОРТЕРА И ДОФАМИНОВОГО РЕЦЕПТОРА D2 АССОЦИИРОВАН С ОСОБЕННОСТЯМИ ТЕЛОСЛОЖЕНИЯ*
}

\begin{abstract}
Одним из актуальных междисииплинарных направлений научных исследований является изучение механизмов, лежащих в основе формирования конституции человека. Полиморфизм генов нейромедиаторных систем довольно часто рассматривается в связи с различными аспектами состояния психики человека и особенностями телосложения. Цель исследования - поиск ассоцииций полиморфизма генов дофаминового транспортёра и дофаминового рецептора D2 с особенностями телосложения и функииональными характеристиками сердечно-сосудистой системы. Использованы материаль комплексного антропогенетического обследования 216 юношей и девушек в возрасте 16-23 лет, проведенного в республике Мордовии. Соматометрическая программа включала измерение длины и массы тела, обхватов талии и бёдер, толщины жировых складок на туловище и конечностях (под лопаткой, на плече, предплечье, животе, бедре и голени). Из функииональных показателей сердечно-сосудистой системь измерены систолическое и диастолическое артериальное давление, частота пульса. У всех респондентов собраны образиь буккального эпителия для генотипирования по локусу 3'- UTR VNTR DAT1 дофаминового переносчика и по локусу DRD2/ANKK1 Taq1A (rs1800497) дофаминового рецептора второго типа. С помощью U-критерия Манна-Уитни проведен сравнительный анализ средних значений морфофункциональных показателей в группах носителей различных генотипов исследуемых генов, по результатам которого выявлены достоверно значимые $(p<0,05)$ ассоциачии: у девушек, обладающих хотя бы одним аллелем 9 по локусу DAT1 выше значения массы тела и обхвата бедер; у девушек - носителей генотипа $C / C$ по локусу DRD2/ANKK1 Taq1A больше показатели массы тела, индекса массы тела, обхвата талии, жировых складок на животе, плече и бедре, а также
\end{abstract}

Васильева Александра Александровна - магистр (биология, антропология), аспирант кафедры антропологии биологического факультета, МГУ им. М.В. Ломоносова (Москва, Ленинские горы, д. 1, стр. 12). Эл. почта: vasileva@mail.bio.msu.ru.

Васильев Василий Александрович - к.б.н., старший научный сотрудник лаборатории организации генома, Институт биологии гена РАН (Москва, улица Вавилова, д. 34/5). Эл. почта: shunka@mail.ru

Негашева Марина Анатольевна - д.б.н., профессор кафедры антропологии биологического факультета, МГУ им. М.В. Ломоносова (Москва, Ленинские горы, д. 1, стр. 12). Эл. почта: negasheva@mail.ru

* Работа выполнена при финансовой поддержке гранта Российского фонда фундаментальных исследований № 18-09-00290 «Биологические и социальные факторы микроэволюционных изменений морфофункционального статуса и уровня полового диморфизма в популяциях современного населения» и программы «Постгеномные технологии и перспективные решения в биомедицине» 
выле частота пульса по сравнению с обладательницами других генотипов. Для юношей достоверных различий морфофункциональных признаков у носителей разных генотипов обнаружено не было. Выявленные ассоциации полиморфизма генов DAT1 и DRD2 с морфофункииональными характеристиками, возможно, обусловлены комплексным влиянием генетических факторов на формирование особенностей телосложения в прочессе онтогенеза человека. Полученные результаты могут представлять интерес для исследователей, занимаюшихся изучением генетических основ морфологической конституции, а также могут быть использованы в персонализированной медицине.

Ключевые слова: антропометрия; индекс массы тела; жироотложение; молодёжь Мордовии; генетика человека; DAT1; DRD2/ANKK1 Taq1A

\section{Введение}

Ген дофаминового транспортёра $D A T 1$ и ген дофаминового рецептора второго типа $D R D 2$ - одни из наиболее популярных у исследователей генов дофаминовой системы, которые часто рассматривают в связи с различными аспектами состояния психики человека. В последнее время полиморфизм этих генов также изучается в ассоциации с телосложением.

Переносчик дофамина ( $S L C 6 A 3$, или $D A T 1)$ играет важную роль в дофаминергической нейротрансмиссии, ограничивая активность дофаминергической системы в синапсах путем обратного захвата нейромедиатора в пресинаптический терминал. Ген человеческого транспортера дофамина (DAT1/SLC6A3) локализован на хромосоме 5p15.3. В данном гене обнаружен VNTR-полиморфизм (варьирующее число тандемных повторов) в 3'-некодирующей области (3'UTR) с числом повторов от 3 до 11. Длина одного повтора 40 пар оснований (п.н.). Два наиболее часто встречающихся в популяциях аллеля состоят из 9 и 10 повторов (Vandenbergh et al. 1992). Повышенный уровень экспрессии DAT1 чаще связывают с аллелем 10, чем с аллелем 9 (VanNess et al. 2005), хотя некоторые исследователи сообщали об обратном (Van Dyck et al. 2005) или об отсутствии ассоциаций между генотипами и показателями экспрессии DAT1 (Krause et al. 2006, Costa et al. 2011). Функциональный полиморфизм DAT1 VNTR напрямую изменяет плотность и активность дофаминового транспортёра в мозге, в основном, в полосатом теле. У лиц, имеющих две копии аллеля 10, концентрация переносчика выше и, значит, меньше дофамина в синаптической щели, чем у носителей аллеля 9 (Heinz et al. 2000). Следовательно, пресинаптический нейрональный мембранный белок DAT1 играет ключевую роль в прекращении нейротрансмиссии дофамина благодаря активному обратному захвату дофамина в пресинаптический терминал (Giros, Caron 1993). Ген DATl (SLC6A3) участвует в эмоциональной обработке данных и связанных с нарушением регуляции передачи дофамина патологиях, например, в развитии депрессивного расстройства. И депрессия, и ожирение ассоциированы с генотипом 9/9 рассматриваемого гена (Bieliński et al. 2017). На примере группы из 506 женщин была показана связь гомозиготности по аллелю с девятью повторами и более высоких значений индекса массы тела (ИМТ) (Sikora et al. 2013). Другие исследователи не выявили связи гена DAT1 с ИМТ и ожирением (Uzun et al. 2015).

Ген $D R D 2$, кодирующий дофаминовый рецептор $\mathrm{D} 2$, расположен на длинном плече хромосомы 11 (11q22.3-11q23.1) (Eubanks et al. 1992). Первоначально считалось, 
что расположенный в 3'-некодирующем регионе однонуклеотидный полиморфизм (rs1800497) DRD2 Taq1A (замена нуклеотидов C/T) относится к гену DRD2. Этот полиморфизм активно изучался как ген-кандидат в связи с психическими заболеваниями, так, например, аллель Т (вариант А1) связан с опиатовой зависимостью (Doehring et al. 2009), а аллель С (вариант A2) - с шизофренией (Nymberg et al. 2014). Однако в результате точного секвенирования выяснилось, что этот полиморфизм находится рядом с геном $D R D 2$ в пределах гена $A N K K 1$ протеинкиназы PKK2, белка системы передачи пострецепторных внутриклеточных сигналов. Современное обозначение локуса - DRD2/ ANKK1 Taq1A. Функциональный полиморфизм вызывает замещение аминокислоты (Glu713Lys) в структуре фермента киназы, что может влиять на специфику связывания им субстрата и изменять нейротрансмиссию дофамина. Так, у носителей аллеля T (A1) снижен уровень связывания дофамина с рецептором D2 в полосатом теле по сравнению с носителями С (A2) аллеля (Savitz et al. 2013). Имеются данные о том, что rs180049 способен регулировать уровень экспрессии гена DRD2 (Doehring et al. 2009). В то же время некоторые учёные считают, что данный полиморфизм не оказывает существенного влияния на доступность дофамина для рецептора (Smith et al. 2017). Согласно существующим данным среди лиц, страдающих психогенным перееданием (англ. bingeeating disorder) большинство являются гомозиготами по аллелю C rs1800497 (Davis et al. 2012). Однако не все исследователи приходят к такому выводу, поскольку не находят связей между рассматриваемым полиморфизмом и данным заболеванием (Benton, Young, 2016, Palmeira et al. 2019). Некоторые учёные считают, что при определённых условиях повышенному жироотложению могут способствовать и генотип $\mathrm{C} / \mathrm{C}$, и генотип Т/Т (Stice et al. 2015). Аллель Т по некоторым данным связан с повышенным ИМТ (Stice et al. 2008). У носителей аллеля Т, независимо от того, страдают они ожирением или нет, могут быть снижены исполнительные функции (Ariza et al. 2012). Кроме всего прочего, молодые люди обоих полов, которые имеют генотип Т+ и обладают избыточной массой тела, испытывают трудности в её снижении (Winkler et al. 2012). Среди страдающих ожирением детей и подростков в белорусской популяции значимо больше встречаются носители генотипа Т/Т (Вязова, Солнцева 2018). Было показано, что обладатели Т+ генотипа более склонны к употреблению жареных блюд и продуктов с высоким с держанием сахара, чем носители Т- генотипа (Rivera-Iñiguez et al. 2019).

Цель данного исследования - поиск ассоциаций полиморфизма генов DAT1 и $D R D 2$ с особенностями телосложения и функциональными характеристиками сердечно-сосудистой системы.

\section{Материалы и методы}

В работе использованы данные комплексного антропогенетического обследования 216 условно здоровых юношей и девушек в возрасте 16-23 лет, проведенного в республике Мордовии (г. Саранск и сёла Зубово-Полянского района). Соматометрическая программа включала измерение длины и массы тела, обхватов талии и бёдер, толщины жировых складок на туловище и конечностях (под лопаткой, на плече, предплечье, животе, бедре и голени) (Негашева 2017). Из функциональных показателей сердечно-сосудистой системы были измерены систолическое и диастолическое артериальное давление, частота пульса. Все материалы комплексного обследования, анализируемые в работе, собраны с соблюдением правил биоэтики, подписанием 
протоколов информированного согласия и деперсонифицированием данных (экспертное заключение Комиссии МГУ по биоэтике, протокол № 55 от 26.03.2015).

По этнической принадлежности 73,6 \% участников исследования русские, у $25,0 \%$ респондентов один из родителей русский, а другой - мордвин или оба родителя мордвины, 1,4 \% обследованных - иноэтничные участники. Статистически значимых отличий по морфофункциональным признакам у представителей разноэтничных групп найдено не было, поэтому они были объединены в общую выборку.

Геномную ДНК выделяли из буккального эпителия с помощью набора реагентов для выделения ДНК из клинического материала «РИБО-преп» (ФБУН ЦНИИ Эпидемиологии Роспотребнадзора, Москва) согласно протоколу производителя. Амплификацию изученных локусов проводили методом локусспецифичной полимеразной цепной реакции синтеза ДНК. Для амплификации локусов DAT1 3'-UTR VNTR и DRD2 rs1800497 использовали набор реагентов GenePak ${ }^{\circledR}$ PCR MacterMix Core (OOO «Лаборатория Изоген») согласно протоколу производителя. Последовательности и температуры отжига праймеров представлены в таблице 1. Условия амплификации включали начальную денатурацию при $94{ }^{\circ} \mathrm{C}$ в течение 4-х мин и 35 циклов (30 циклов для $D A T 1)$, состоящих из трех стадий: денатурация - 1 мин, $94{ }^{\circ} \mathrm{C}$; отжиг праймера - 1 мин, $\mathrm{X}{ }^{\circ} \mathrm{C}$ (таблица 1); элонгация - 1 мин, $72{ }^{\circ} \mathrm{C}$. На последней стадии проводили заключительную элонгацию при $72{ }^{\circ} \mathrm{C}$ в течение 2 мин (10 мин для $\left.D A T 1\right)$. Для определения SNP (rs1800497) продукты амплификации делили на равные аликвоты по 10 мкл, одну из которых обрабатывали эндонуклеазой рестрикции Taq1 («Fermentas») (5 ед. на пробу) при $65^{\circ} \mathrm{C}$ в течение ночи. Аллели идентифицировали по размерам фрагментов ДНК после их электрофоретического разделения в агарозном геле. Продукты рестрикции фракционировали в 2 \%-ном агарозном геле с прокраской бромистым этидиумом. Результаты анализировали и фотографировали на приборе «BioDocAnalyze».

Таблица 1

\section{Полиморфизм локусов DAT1 VNTR, DRD2 rs1800497 и условия проведения полимеразной цепной реакции}

\begin{tabular}{|c|c|c|c|c|}
\hline Локус & $\begin{array}{c}\text { Последовательности } \\
\text { праймеров }\end{array}$ & $\begin{array}{c}\text { Температу- } \\
\text { ра отжига } \\
\text { праймеров } \\
\text { (X) }\end{array}$ & $\begin{array}{l}\text { Рестрик- } \\
\text { таза }\end{array}$ & $\begin{array}{c}\text { Аллели } \\
\text { (размер } \\
\text { фрагмен- } \\
\text { тов, п.н.) }\end{array}$ \\
\hline $\begin{array}{l}\text { DAT1 } \\
\text { 3'- UTR VNTR }\end{array}$ & $\begin{array}{l}F: 5^{\prime} \text {-tgcggtgtagggaacggcctgag-3' } \\
\text { R:5' -cttcctggaggtcacggctcaagg-3' }\end{array}$ & $68^{\circ} \mathrm{C}$ & - & $\begin{array}{c}11(520) \\
10(480) \\
9(440) \\
8(400) \\
7(360)\end{array}$ \\
\hline $\begin{array}{l}D R D 2 / \\
\text { ANKK1 Taq1A } \\
\text { (rs1800497) }\end{array}$ & $\begin{array}{l}\text { F: 5'-ccgtcgacggetggccaagttgtcta-3' } \\
\text { R: 5'-ccgtcgacccttcctgagtgtcatca-3' }\end{array}$ & $66^{\circ} \mathrm{C}$ & $\begin{array}{l}\text { Taq } 1, \\
65^{\circ} \mathrm{C}\end{array}$ & $\begin{array}{c}\mathrm{T}(310) \\
\mathrm{C}(180,130)\end{array}$ \\
\hline
\end{tabular}

* Примечание. $\mathrm{F}$ - прямой праймер, $\mathrm{R}$ - обратный праймер, п.н. - пар нуклеотидов.

Статистическая обработка полученных данных была проведена в пакете программ Statistica 10.0. На предварительном этапе статистического анализа рас- 
пределение всех морфологических признаков было проверено на нормальность с помощью критерия Колмогорова-Смирнова с поправкой Лилиефорса. Затем для оценки достоверности межгрупповых различий показателей телосложения у индивидов с разными генотипами по двум локусам был применён непараметрический U-критерий Манна-Уитни.

\section{Результаты}

Средние значения длины и массы тела обследованных юношей составили 177,2 см и 71,0 кг; девушек - 163,4 см и 56,1 кг. У 10,2 \% участников исследования

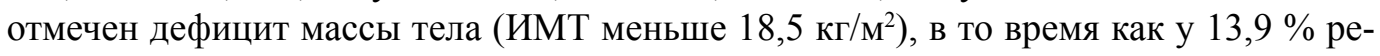

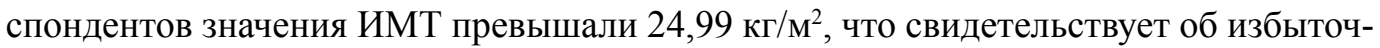
ной массе тела или ожирении (ИМТ рассчитан по формуле: ИМТ $=\mathrm{P} / \mathrm{L}^{2}$, где $\mathrm{P}$ - масса тела в килограммах, L - длина тела в метрах). Частоты встречаемости различных генотипов по локусам $D A T 1$ и $D R D 2 / A N K K 1$ Taq1А в выборке приведены в таблице 2. Для более эффективного поиска возможных морфогенетических ассоциаций все генотипы были сгруппированы по наличию/отсутствию аллеля 9 для локуса DAT1 и по наличию/отсутствию аллеля Т по локусу $D R D 2 / A N K K 1$, поскольку численность индивидов с каждым отдельно взятым генотипом относительно невелика.

Таблица 2

\section{Частоты встречаемости аллельных вариантов исследуемых генов в объединённой выборке}

\begin{tabular}{|c|c|c|c|}
\hline Локус & Генотип/Аллель & Численность & $\begin{array}{l}\text { Частота встречаемо- } \\
\text { сти генотипа/аллеля }\end{array}$ \\
\hline \multirow{2}{*}{ DAT1 } & $\begin{array}{c}9+(9 / 10,9 / 9,8 / 9) \\
9-(10 / 10,8 / 10,7 / 10,10 / 11)\end{array}$ & $\begin{array}{c}90 \\
126\end{array}$ & $\begin{array}{l}0,417 \\
0,583\end{array}$ \\
\hline & $\begin{array}{c}11 \\
10 \\
9 \\
8 \\
7\end{array}$ & $\begin{array}{c}4 \\
325 \\
100 \\
2 \\
1\end{array}$ & $\begin{array}{l}0,010 \\
0,752 \\
0,231 \\
0,005 \\
0,002\end{array}$ \\
\hline \multirow{2}{*}{$\begin{array}{l}\text { DRD2/ANKK } 1 \\
\text { Taq1A }\end{array}$} & $\begin{array}{c}\mathrm{T}+(\mathrm{T} / \mathrm{T}, \mathrm{T} / \mathrm{C}) \\
\mathrm{T}-(\mathrm{C} / \mathrm{C})\end{array}$ & $\begin{array}{c}166 \\
50\end{array}$ & $\begin{array}{l}0,769 \\
0,231\end{array}$ \\
\hline & $\begin{array}{l}\mathrm{T} \\
\mathrm{C}\end{array}$ & $\begin{array}{l}171 \\
261\end{array}$ & $\begin{array}{l}0,396 \\
0,604\end{array}$ \\
\hline
\end{tabular}

В таблицах 3 и 4 представлены результаты сравнительного анализа средних значений морфофункциональных характеристик у носителей различных генотипов генов $D A T 1$ и $D R D 2$. 
Таблица 3

\section{Морфофункциональные характеристики носителей различных генотипов гена $D A T 1$}

\begin{tabular}{|c|c|c|c|c|c|c|c|c|}
\hline \multirow{4}{*}{ Признак } & \multicolumn{4}{|c|}{ Юноши } & \multicolumn{4}{|c|}{ Девушки } \\
\hline & \multicolumn{8}{|c|}{ Генотип } \\
\hline & \multicolumn{2}{|c|}{$\begin{array}{c}9+ \\
(\mathrm{N}=54)\end{array}$} & \multicolumn{2}{|c|}{$\begin{array}{c}9- \\
(\mathrm{N}=60)\end{array}$} & \multicolumn{2}{|c|}{$\begin{array}{c}9+ \\
(\mathrm{N}=36)\end{array}$} & \multicolumn{2}{|c|}{$\begin{array}{c}9- \\
(\mathrm{N}=66)\end{array}$} \\
\hline & $\mathbf{M}$ & SD & $\mathbf{M}$ & SD & $\mathbf{M}$ & SD & $\mathbf{M}$ & SD \\
\hline Масса тела, кг & 71,9 & 12,5 & 70,2 & 11,9 & $58,2 *$ & 7,5 & $55,0 *$ & 7,6 \\
\hline Длина тела, см & 177,3 & 6,4 & 177,0 & 6,7 & 164,3 & 5,5 & 163,0 & 5,8 \\
\hline $\begin{array}{l}\text { Индекс массы тела } \\
(\text { ИМТ), кг/м² }\end{array}$ & 22,9 & 3,6 & 22,3 & 3,2 & 21,6 & 3,3 & 20,7 & 2,6 \\
\hline Обхват талии, см & 78,4 & 7,9 & 77,8 & 7,7 & 70,0 & 5,6 & 69,0 & 6,0 \\
\hline Обхват бёдер, см & 96,4 & 7,6 & 95,1 & 7,1 & $95,7^{*}$ & 6,2 & $93,0^{*}$ & 6,0 \\
\hline $\begin{array}{l}\text { Жировая складка } \\
\text { под лопаткой, мм }\end{array}$ & 12,1 & 7,7 & 11,6 & 5,9 & 13,9 & 6,6 & 13,7 & 5,6 \\
\hline $\begin{array}{l}\text { Жировая складка } \\
\text { на плече, мм }\end{array}$ & 11,7 & 8,6 & 11,0 & 5,6 & 18,3 & 6,2 & 17,4 & 5,6 \\
\hline $\begin{array}{l}\text { Жировая складка } \\
\text { на предплечье, мм }\end{array}$ & 5,5 & 2,8 & 6,0 & 2,9 & 8,0 & 4,1 & 7,9 & 3,4 \\
\hline $\begin{array}{l}\text { Жировая складка } \\
\text { на животе, мм }\end{array}$ & 16,2 & 12,0 & 17,7 & 11,7 & 22,4 & 9,9 & 23,0 & 9,6 \\
\hline $\begin{array}{l}\text { Жировая складка } \\
\text { на бедре, мм }\end{array}$ & 17,0 & 10,6 & 16,0 & 8,7 & 34,5 & 7,9 & 31,8 & 9,0 \\
\hline $\begin{array}{l}\text { Жировая складка } \\
\text { на голени, мм }\end{array}$ & 13,3 & 6,6 & 13,5 & 5,7 & 20,5 & 7,2 & 19,4 & 6,2 \\
\hline $\begin{array}{l}\text { Систолическое } \\
\text { артериальное давле- } \\
\text { ние, мм рт. ст. }\end{array}$ & 140,4 & 16,5 & 136,4 & 14,2 & 124,8 & 13,5 & 120,2 & 10,5 \\
\hline $\begin{array}{l}\text { Диастолическое } \\
\text { артериальное давле- } \\
\text { ние, мм рт. ст. }\end{array}$ & 74,7 & 7,8 & 74,8 & 8,1 & 75,4 & 8,1 & 75,9 & 9,3 \\
\hline $\begin{array}{l}\text { Частота пульса, } \\
\text { ударов в минуту }\end{array}$ & 74,7 & 12,4 & 75,5 & 13,2 & 82,0 & 13,0 & 82,5 & 12,0 \\
\hline
\end{tabular}

Примечание. М - среднее арифметическое значение, SD - среднеквадратичное отклонение. * уровень значимости $\mathrm{p}<0,05$. 
Таблица 4

\section{Морфофункциональные характеристики носителей различных генотипов гена $D R D 2$}

\begin{tabular}{|c|c|c|c|c|c|c|c|c|}
\hline \multirow{4}{*}{ Признак } & \multicolumn{4}{|c|}{ Юноши } & \multicolumn{4}{|c|}{ Девушки } \\
\hline & \multicolumn{8}{|c|}{ Генотип } \\
\hline & \multicolumn{2}{|c|}{$\begin{array}{c}T+ \\
(N=94)\end{array}$} & \multicolumn{2}{|c|}{$\begin{array}{c}\mathbf{T}- \\
(\mathbf{N}=\mathbf{2 0})\end{array}$} & \multicolumn{2}{|c|}{$\begin{array}{c}T+ \\
(\mathbf{N}=72)\end{array}$} & \multicolumn{2}{|c|}{$\begin{array}{c}\mathrm{T}- \\
(\mathbf{N}=\mathbf{3 0})\end{array}$} \\
\hline & $\mathbf{M}$ & SD & $\mathbf{M}$ & SD & $\mathbf{M}$ & SD & $\mathbf{M}$ & SD \\
\hline Масса тела, кг & 71,0 & 12,3 & 71,3 & 12,0 & $55,2 *$ & 6,7 & $58,7^{*}$ & 9,4 \\
\hline Длина тела, см & 177,2 & 6,5 & 177,0 & 6,7 & 163,6 & 5,9 & 163,0 & 5,3 \\
\hline $\begin{array}{l}\text { Индекс массы тела } \\
\text { (ИМТ), кг/м² }\end{array}$ & 22,6 & 3,6 & 22,3 & 3,1 & $20,5^{* *}$ & 2,2 & $22,1 * *$ & 3,8 \\
\hline Обхват талии, см & 77,9 & 7,6 & 78,8 & 8,3 & $68,5^{*}$ & 5,1 & $71,4^{*}$ & 6,8 \\
\hline Обхват бёдер, см & 95,8 & 7,5 & 95,3 & 6,2 & 93,3 & 5,2 & 95,6 & 8,0 \\
\hline $\begin{array}{l}\text { Жировая } \quad \text { складка } \\
\text { под лопаткой, мм }\end{array}$ & 11,7 & 6,3 & 12,7 & 9,0 & 13,3 & 5,2 & 14,8 & 7,4 \\
\hline $\begin{array}{l}\text { Жировая складка на } \\
\text { плече, мм }\end{array}$ & 11,4 & 7,4 & 10,6 & 6,1 & $16,7^{*}$ & 4,6 & $20,0^{*}$ & 7,4 \\
\hline $\begin{array}{l}\text { Жировая складка на } \\
\text { предплечье, мм }\end{array}$ & 5,7 & 2,7 & 6,1 & 3,4 & 7,6 & 3,1 & 8,8 & 4,5 \\
\hline $\begin{array}{l}\text { Жировая складка на } \\
\text { животе, мм }\end{array}$ & 16,5 & 11,6 & 19,3 & 12,6 & $21,0 * *$ & 9,2 & $27,0 * *$ & 9,6 \\
\hline $\begin{array}{l}\text { Жировая складка на } \\
\text { бедре, мм }\end{array}$ & 16,1 & 8,8 & 18,5 & 13,1 & $31,5^{*}$ & 8,2 & $35,7^{*}$ & 9,2 \\
\hline $\begin{array}{l}\text { Жировая складка на } \\
\text { голени, мм }\end{array}$ & 13,4 & 6,2 & 13,5 & 5,8 & 19,0 & 6,1 & 21,9 & 7,3 \\
\hline $\begin{array}{l}\text { Систолическое } \\
\text { артериальное давле- } \\
\text { ние, мм рт. ст. }\end{array}$ & 138,4 & 15,4 & 138,1 & 15,6 & 121,8 & 11,9 & 122,3 & 12,0 \\
\hline $\begin{array}{l}\text { Диастолическое ар- } \\
\text { териальное давле- } \\
\text { ние, мм рт. ст. }\end{array}$ & 74,7 & 8,2 & 75,1 & 6,9 & 75,1 & 8,4 & 77,3 & 9,8 \\
\hline $\begin{array}{l}\text { Частота пульса, уда- } \\
\text { ров в минуту }\end{array}$ & 74,7 & 13,4 & 77,1 & 9,4 & $80,3^{*}$ & 11,3 & $87,2^{*}$ & 13,5 \\
\hline
\end{tabular}

Примечание. М - среднее арифметическое значение, SD - среднеквадратичное отклонение. * уровень значимости $\mathrm{p}<0,05, * *$ - уровень значимости $\mathrm{p}<0,01$. 


\section{Обсуждение}

Обследованные юноши и девушки Мордовии по значениям тотальных размеров тела (длина и масса тела, ИМТ, обхваты талии и бёдер) и функциональным параметрам сердечно-сосудистой системы (артериальное давление и частота пульса) соответствуют морфофункциональным показателям, характерным для своих сверстников из других регионов России, например, Москвы, Самары, Архангельска (Калмин и др. 2010, Колокольиев, Лебединский 2012, Бондарева и др. 2016, Синева и др. 2017).

Анализ результатов распределения аллельных вариантов генотипов по локусам $D A T 1$ и $D R D 2 / A N K K 1$ Taq1А в объединённой выборке показал наибольшую частоту встречаемости вариантов $10 / 10$ и $9 / 10(55,6 \%$ и $36,6 \%$ респондентов соответственно) для локуса $D A T 1$ и генотипа T/C (74,5 \% участников исследования) локуса $D R D 2 /$ $A N K K$ Taq1A, что согласуется с данными других авторов о распределении частот генотипов и аллелей двух локусов у русских и мордвы (Hu et al. 1999, Flegontova et al. 2009, Butovskaya et al. 2013).

С помощью U-критерия Манна-Уитни проведено сравнение значений морфофункциональных показателей юношей и девушек в группах носителей разных генотипов по двум локусам. В мужской группе между носителями генотипа 9+ и обладателями генотипа 9- локуса $D A T 1$ не было обнаружено достоверных различий, в то время как в группе девушек были выявлены статистически значимые различия между носителями разных аллельных вариантов $D A T 1(\mathrm{p}<0,05)$ : у обладательниц генотипа 9+ больше средние значения массы тела (на 3,2 кг) и обхвата бёдер (на 2,7 см), чем у девушек, имеющих генотип 9- (таблица 3 , рис. 1-2). Также следует обратить внимание, что среди девушек с генотипом 9+ доля индивидов с избыточной массой тела (ИМТ $>24,9$ кг/

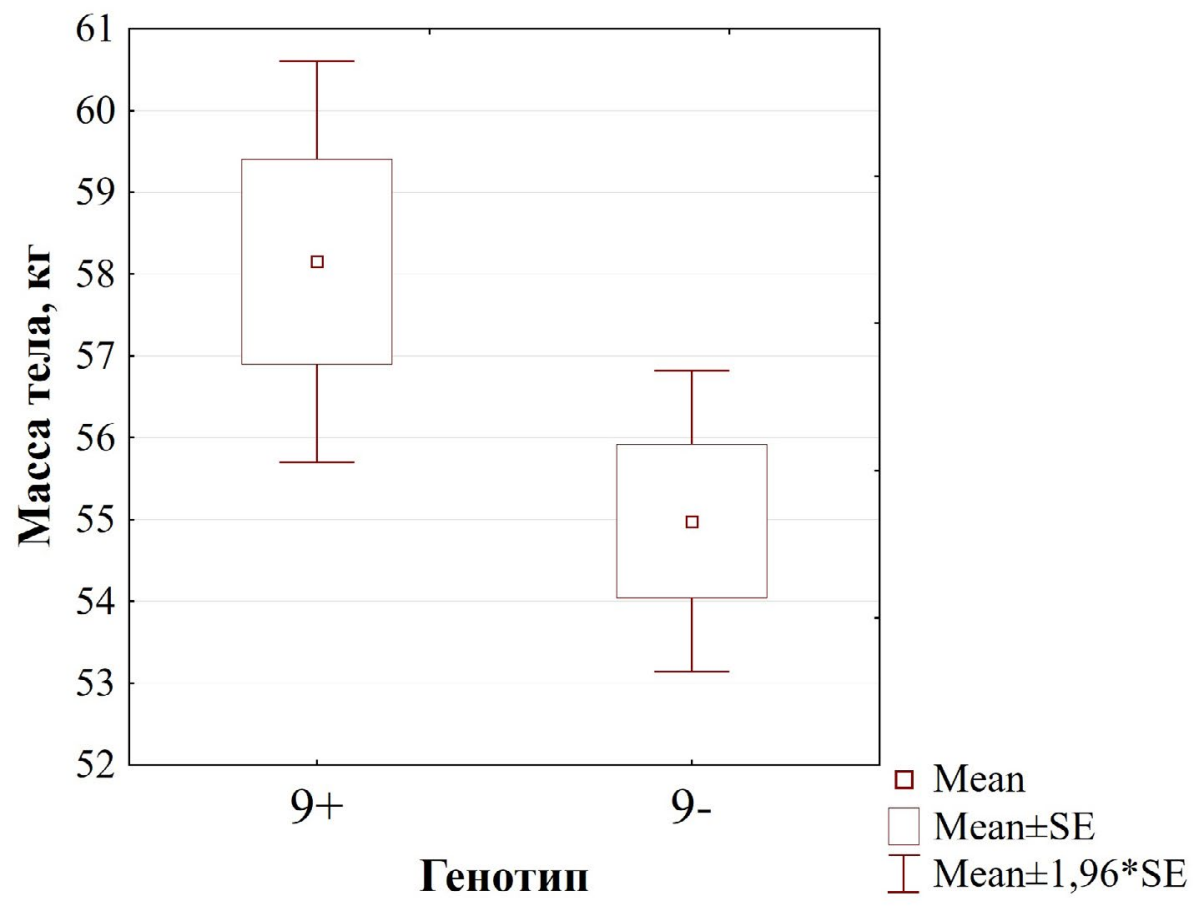

Рис. 1. Иллюстрачия результатов сравнительного анализа средних значений массы тела в группах девушек с различными генотипами по гену DAT1. 
$\left.\mathrm{M}^{2}\right)$ в 3,5 раза больше (11 \%) по сравнению с группой носительниц генотипа 9- (3\%; $\mathrm{p}=0,0496)$. Полученные результаты согласуются с данными других авторов о связи генотипа 9+ с повышенной массой тела (Sikora et al. 2013, Bieliński et al. 2017).

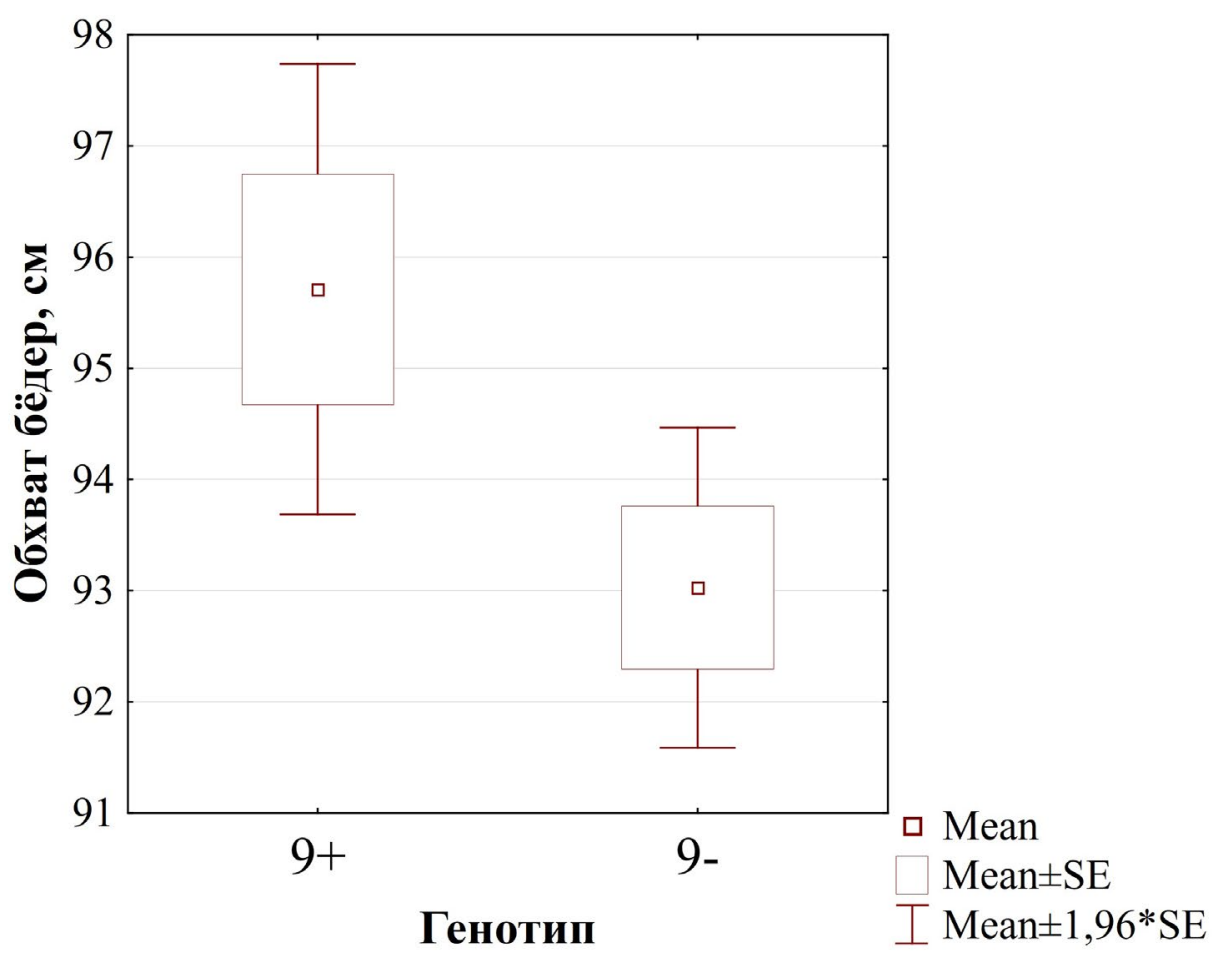

Рис. 2. Иллюстрация результатов сравнительного анализа средних значений обхвата бёдер в группах девушек с различными генотипами по гену DAT1.

В подгруппах мужчин с наличием и отсутствием аллеля Т полиморфизма rs1800497 (DRD2/ANKK1 Taq1A) не было найдено значимых отличий в особенностях телосложения. Для девушек же при сравнении аналогичных подгрупп получены статистически достоверные различия по нескольким морфофункциональным признакам. У девушек с генотипом Т- (т.е. генотипом $\mathrm{C} / \mathrm{C}$ ) по сравнению с носительницами генотипа T+ (генотипы T/T или T/C) выше средние значения массы тела (на 3,5 кг), индекса массы тела, больше обхват талии (на 2,9 см), толще жировые складки на плече, животе и бедре, а также выше частота пульса, p<0,05 (таблица 4, рисунки 3-5).

Девушки с избыточной массой тела (ИМТ $>24,9$ кг/м²) встречаются среди респонденток, имеющих генотип Т-, в 2,5 раза чаще, чем в группе носительниц генотипа $\mathrm{T}+(10 \%$ и $4 \%$ соответственно; $\mathrm{p}=0,118)$. Полученные в нашем исследовании результаты об ассоциации генотипа Т- с повышенной массой тела согласуются с некоторыми литературными данными, в которых сообщается о склонности взрослых людей - носителей генотипа Т- к психогенному и эмоциональному перееданию (Davis et al. 2012) и повышенному жироотложению (Stice et al. 2015). Хотя более распространённой является гипотеза о связи аллеля Т с низкими уровнями дофамина в мозге и с ожирением (Stice et al. 2008, Winkler et al. 2012, Вязова, Солнцевва 2018, Rivera-Iñiguez et al. 2019). 


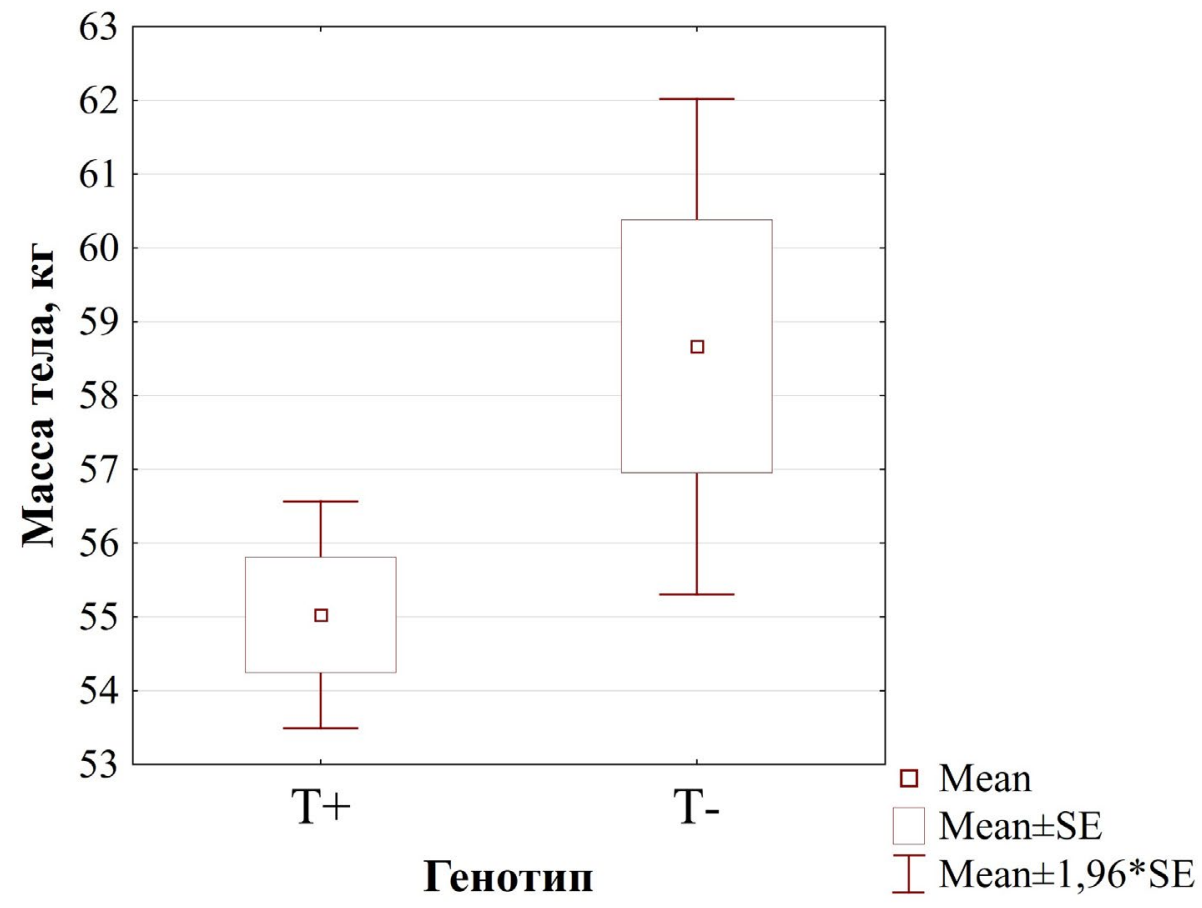

Рис. 3. Иллюстрация результатов сравнительного анализа средних значений массы тела в группах девушек с различными генотипами по гену DRD2.

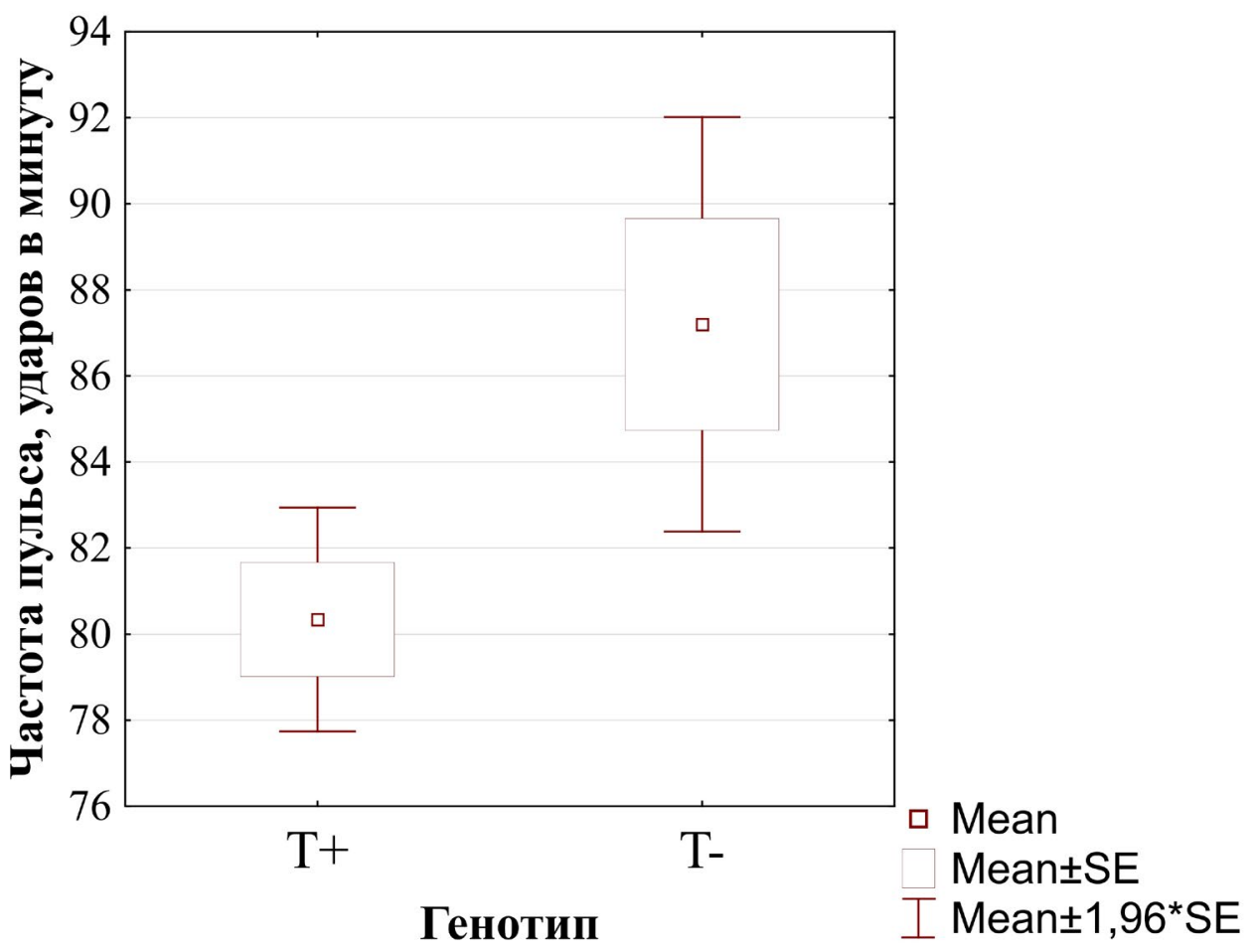

Рис. 4. Иллюстрация результатов сравнительного анализа средних значений частоть пульса в группах девушек с различными генотипами по гену DRD2. 


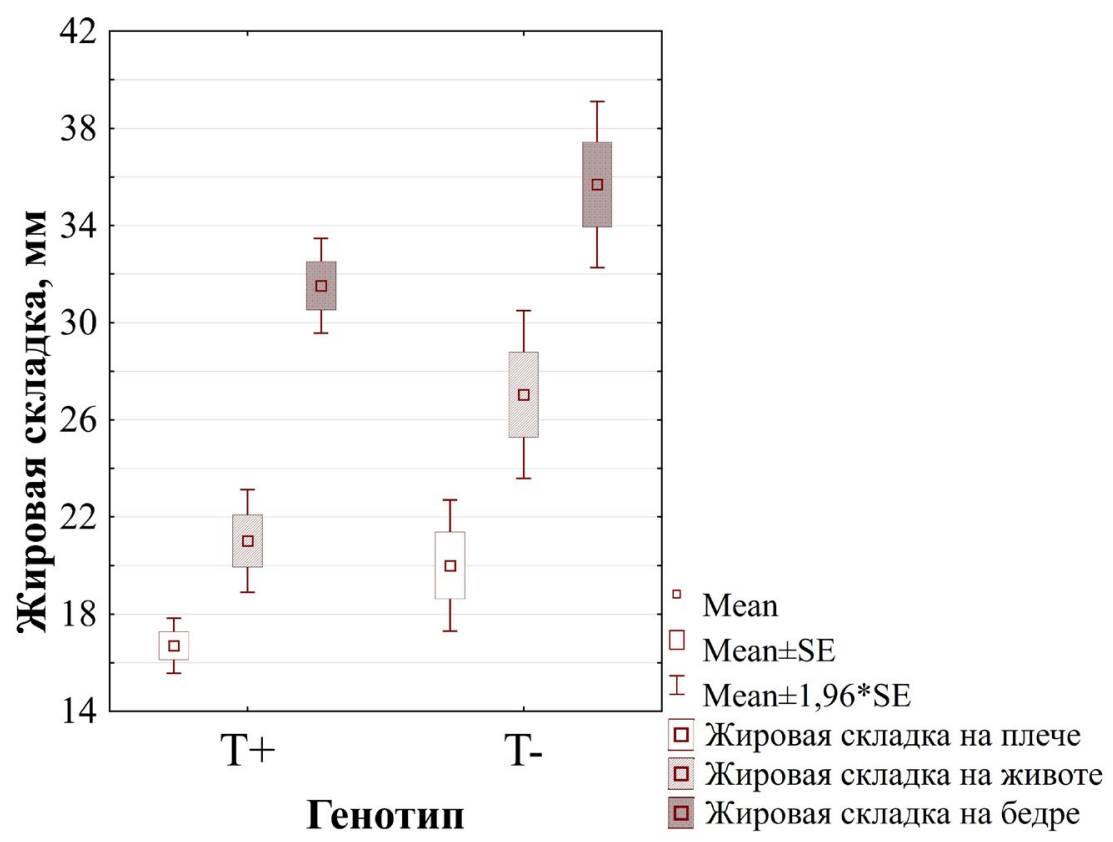

Рис. 5. Иллюстрация результатов сравнительного анализа средних значений жировых складок в группах девушек с различными генотипами по гену DRD2.

Многие междисциплинарные исследования посвящены изучению генетических механизмов, лежащих в основе формирования особенностей конституции человека. Полиморфизм генов нейромедиаторных систем в последнее время рассматривается не только в связи с различными аспектами состояния психики человека, но и с особенностями телосложения. Существуют две гипотезы, объясняющие взаимосвязь избыточного жироотложения с вариабельностью генов дофаминовой системы. Одна концепция предполагает, что более высокая доступность дофамина приводит к возрастающей чувствительности к вознаграждению и более сильному желанию употреблять вкусную пищу, которая может привести к перееданию и, следовательно, к ожирению (Davis et al. 2007). Другая гипотеза гласит, что низкие уровни дофамина в мозге человека могут привести к синдрому дефицита удовольствия и компенсироваться перееданием для достижения удовольствия (Avsar et al. 2017). Генотип 9+ по локусу DAT1 связан с пониженной концентрацией дофамина в мозге, а генотип Т- по локусу $D R D 2 / A N K K 1$ Taq1 A - с повышенной. Оба этих генотипа по нашим данным ассоциированы с избыточной массой тела и повышенным жироотложением (в большей степени генотип Т-) у девушек. В связи с актуальностью поиска ассоциаций генетического полиморфизма с морфофункциональными и психосоматическими особенностями авторы считают необходимым проведение дальнейших исследований влияния генов дофаминовой системы на особенности телосложения с расширением спектра генетических маркеров и увеличением численности выборок.

\section{Заключение}

По результатам проведенного антропогенетического исследования в женской выборке выявлены достоверно значимые ассоциации полиморфизма генов DAT1 и 
$D R D 2$ с морфофункциональными признаками: у носителей хотя бы одного аллеля 9 по локусу DAT1 выше значения массы тела и обхвата бедер; у обладателей генотипа C/C по локусу DRD2/ANKK1 Taq1А больше масса тела, индекс массы тела, обхват талии, толщина жировых складок на животе, плече и бедре, а также выше показатели частоты пульса по сравнению с носителями других генотипов. Полученные ассоциации, возможно, обусловлены комплексным влиянием генетических факторов на формирование особенностей телосложения (в данном случае, на развитие массы тела, ИМТ и показателей жироотложения) в процессе онтогенеза человека. Выявленные связи полиморфизма генов дофаминового переносчика и дофаминового рецептора второго типа с морфофункциональными показателями могут представлять интерес для исследователей, занимающихся изучением генетических основ морфологической конституции, а также могут быть использованы в персонализированной медицине, например, для корректировки питания пациентов с генетической предрасположенностью к избыточному жироотложению.

\section{Научная литература}

Бондарева Э.А., Негашева М.А., Грудиева А.В., Тарасова Т.В. Ассоциации Т/А-полиморфизма гена FTO с характером жироотложения у юношей и девушек // Вестник Московского университета. Серия ХХІІІ. Антропология. 2016. № 4. С. 69-77.

Вязова Л.С., Солнцева А.В. Взаимное влияние генетического полиморфизма TaqIA гена дофаминового рецептора 2 типа, уровней дофамина и лептина крови на формировании разных форм ожирения у детей // Детская медицина Северо-Запада. 2018. Т. 7. № 1. С. 71.

Калмин О.В., Афанасиевская Ю.С., Самотуга А.В. Оценка особенностей антропометрических параметров распределения соматотипов лиц юношеского возраста г. Краснодара и Краснодарского Края // Известия высших учебных заведений. Поволжский регион. Медицинские науки. 2010. № 1 (13). С. 3-11.

Колокольцев М.М., Лебединский В.Ю. Сравнительная характеристика уровня физического развития студенческой молодежи юношеского возраста Иркутской области // Бюллетень ВСНЦ СО РАМН. 2012. № 6 (88). С. 47-54.

Негашева М.А. Основы антропометрии. Москва: Экон-Информ, 2017.

Синева И.М., Негашева М.А., Попов Ю.М. Сравнительный анализ уровня физического развития студентов разных городов России // Вестник Московского университета. Серия XXIII. Антропология. 2017. № 4. С. 17-27.

Ariza M., Garolera M., Jurado M.A., Garcia-Garcia I., Hernan I., Sánchez-Garre C., Vernet-Vernet M., Sender-Palacios M.J., Marques-Iturria I., Pueyo R., Segura B., Narberhaus A. Dopamine Genes (DRD2/ANKK1-TaqA1 and DRD4-7R) and Executive Function: Their Interaction with Obesity // PLoS One. 2012. Vol. 7. № 7. P. e41482. DOI: 10.1371/journal.pone.0041482.

Avsar O., Kuskucu A., Sancak S., Genc E. Are dopaminergic genotypes risk factors for eating behavior and obesity in adults? // Neurosci. Let., 2017. Vol. 654. Pp. 28-32. DOI: 10.1016/j. neulet.2017.06.023.

Benton D., Young H.A. A meta-analysis of the relationship between brain dopamine receptors and obesity: a matter of changes in behavior rather than food addiction? // Int. J. Obes., 2016. Vol. 40. Suppl. 1. Pp. S12-S21. DOI: 10.1038/ijo.2016.9.

Bieliński M., Jaracz M., Lesiewska N., Tomaszewska M., Sikora M., Junik R., Kamińska A., Tretyn A., Borkowska A. Association between COMT Val158Met and DAT1 polymorphisms and depressive symptoms in the obese population // Neuropsychiatr. Dis. Treat. 2017. Vol.13. Pp. 2221-2229. DOI: 10.2147/NDT.S138565.

Butovskaya P.R., Butovskaya M.L., Vasilyev V.A., Lazebny O.E., Shibalev D.V., Veselovskaya E.V., Udina I.G., Ryskov A.P. Molecular-genetic polymorphisms of dopamine, serotonin and an- 
drogenic systems as molecular markers of success in judo wrestling sportsmen // J. Bioanal. Biomed., 2013. № S3. P. 005. DOI: 10.4172/1948-593X.S3-005.

Costa A., Riedel M., Müller U., Möller H.J., Ettinger U. Relationship between SLC6A3 genotype and striatal dopamine transporter availability: A metaanalysis of human single photon emission computed tomography studies // Synapse. 2011. Vol. 65. № 10. Pp. 998-1005. DOI: 10.1002/ syn.20927.

Davis C., Patte K., Levitan R., Reid C., Tweed S., Curtis C. From motivation to behaviour: a model of reward sensitivity, overeating, and food preferences in the risk profile for obesity // Appetite, 2007. Vol. 48. № 1. Pp. 12-19. DOI: 10.1016/j.appet.2006.05.016.

Davis C., Levitan R.D., Yilmaz Z., Kaplan A.S., Carter J.C., Kennedy J.L. Binge eating disorder and the dopamine D2 receptor: genotypes and sub-phenotypes // Prog. Neuropsychopharmacol. Biol. Psychiatry. 2012. Vol. 38. № 2. P. 328-335. DOI: 10.1016/j.pnpbp.2012.05.002.

Doehring A., Hentig N., Graff J., Salamat S., Schmidt M., Geisslinger G., Harder S., Lotsch J. Genetic variants altering dopamine D2 receptor expression or function modulate the risk of opiate addiction and the dosage requirements of methadone substitution // Pharmacogenet. Genomics. 2009. Vol. 19. № 6. Pp. 407-414. DOI: 10.1097/FPC.0b013e328320a3fd.

Eubanks J.H., Djabali M., Selleri L., Grandy D.K., Civelli O., McElligott D.L., Evans G.A. Structure and linkage of the D2 dopamine receptor and neural cell adhesion molecule genes on human chromosome 11q23 // Genomics. 1992. Vol. 14. № 4. Pp. 1010-1018. DOI: 10.1016/s08887543(05)80124-7.

Flegontova O.V., Khrunin A.V., Lylova O.I., Tarskaia L.A., Spitsyn V.A., Mikulich A.I., Limborska S.A. Haplotype frequencies at the DRD2 locus in populations of the East European Plain // BMC Genet. 2009. Vol. 10. P. 62. DOI: 10.1186/1471-2156-10-62.

Giros B., Caron M.G. Molecular characterization of the dopamine transporter// Trends Pharmacol. Sci., 1993. Vol. 14. № 2. Pp. 43-49. DOI: 10.1016/0165-6147(93)90029-j.

Hu Y., Hakkola J., Oscarson M., Ingelman-Sundberg M. Structural and Functional Characterization of the 5'-flanking Region of the Rat and Human Cytochrome P450 2E1 Genes: Identification of a Polymorphic Repeat in the Human Gene // Biochem. Biophys. Res. Commun. 1999. Vol. 263. № 2. Pp. 286-293. DOI: 10.1006/bbrc.1999.1362.

Krause J., Dresel S.H., Krause K.H., La Fougère C., Zill P., Ackenheil M. Striatal dopamine transporter availability and DAT-1 gene in adults with ADHD: no higher DAT availability in patients with homozygosity for the 10-repeat allele // World J. Biol. Psychiatry. 2006. Vol. 7. № 3. Pp. 152-157. DOI: 10.1080/15622970500518444.

Nymberg C., Banaschewski T., Bokde A.L., Büchel C., Conrod P., Flor H., Frouin V., Garavan H., Gowland P., Heinz A., Ittermann B., Mann K., Martinot J.L., Nees F., Paus T., Pausova Z., Rietschel M., Robbins T.W., Smolka M.N., Ströhle A., Schumann G., Klingberg T. DRD2/ANKK1 polymorphism modulates the effect of ventral striatal activation on working memory performance // Neuropsychopharmacology, 2014. Vol. 39. № 10. Pp. 2357-2365. DOI: 10.1038/npp.2014.83.

Palmeira L., Cunha M., Padez C., Alvarez M., Pinto-Gouveia J., Manco L. Association study of variants in genes FTO, SLC6A4, DRD2, BDNF and GHRL with binge eating disorder (BED) in Portuguese women // Psychiatry Res. 2019 Vol. 273. Pp. 309-311. DOI: 10.1016/j.psychres.2019.01.047.

Rand C.M., Patwari P.P., Rodikova E.A., Zhou L., Berry-Kravis E.M., Wilson R.J., Bech-Hansen T., Weese-Mayer D.E. Rapid-onset obesity with hypothalamic dysfunction, hypoventilation, and autonomic dysregulation: analysis of hypothalamic and autonomic candidate genes // Pediatr. Res. 2011. Vol. 70. № 4. Pp. 375-378. DOI: 10.1203/PDR.0b013e318229474d.

Rivera-Iñiguez I., Panduro A., Ramos-Lopez O., Villaseñor-Bayardo S.J., Roman S. DRD2/ANKK1 TaqI A1 polymorphism associates with overconsumption of unhealthy foods and biochemical abnormalities in a Mexican population // Eat. Weight. Disord., 2019. Vol. 24. № 5. Pp. 835-844. DOI: 10.1007/s40519-018-0596-9.

Savitz J., Hodgkinson C.A., Martin-Soelch C., Shen P.H., Szczepanik J., Nugent A.C., Herscovitch 
P., Grace A.A., Goldman D., Drevets W.C. DRD2/ANKK1 Taq1A polymorphism (rs1800497) has opposing effects on D2/3 receptor binding in healthy controls and patients with major depressive disorder // Int. J. Neuropsychopharmacol., 2013. Vol. 16. № 9. Pp. 2095-2101. DOI: 10.1017/S146114571300045X.

Sikora M., Gese A., Czypicki R., Gąsior M., Tretyn A., Chojnowski J., Bieliński M., Jaracz M., Kamińska A., Junik R., Borkowska A. Correlations between polymorphisms in genes coding elements of dopaminergic pathways and body mass index in overweight and obese women // Endokrynol. Pol. 2013. Vol. 64. № 2. Pp. 101-107.

Smith C.T., Dang L.C., Buckholtz J.W., Tetreault A.M., Cowan R.L., Kessler R.M., Zald D.H. The impact of common dopamine D2 receptor gene polymorphisms on D2/3 receptor availability: C957T as a key determinant in putamen and ventral striatum // Transl. Psychiatry. 2017. Vol. 7. № 4. P. e1091. DOI: 0.1038/tp.2017.45.

Stice E., Burger K.S., Yokum S. Reward Region Responsivity Predicts Future Weight Gain and Moderating Effects of the TaqIA Allele // J. Neurosci. 2015. Vol. 35. № 28. Pp. 10316-10324. DOI: 10.1523/JNEUROSCI.3607-14.2015.

Stice E., Spoor S., Bohon C., Small D.M. Relation between obesity and blunted striatal response to food is moderated by TaqIA A1 allele // Science. 2008. Vol. 322. № 5900. Pp. 449-452. DOI: 10.1126/science.1161550.

Uzun M., Saglar E., Kucukyildirim S., Erdem B., Unlu H., Mergen H. Association of VNTR polymorphisms in DRD4, 5-HTT and DAT1 genes with obesity // Arch. Physiol. Biochem. 2015. Vol. 121. № 2. Pp. 75-79. DOI: 10.3109/13813455.2014.985686.

Van Dyck C.H., Malison R.T., Jacobsen L.K., Seibyl J.P., Staley J.K., Laruelle M., Baldwin R.M., Innis R.B., Gelernter J. Increased dopamine transporter availability associated with the 9-repeat allele of the SLC6A3 gene // J. Nucl. Med. 2005. Vol. 46. № 5. Pp. 745-751.

Vandenbergh D.J., Persico A.M., Hawkins A.L., Griffin C.A., Li X., Jabs E.W., Uhl G.R. Human dopamine transporter gene (DAT1) maps to chromosome 5p15. 3 and displays a VNTR // Genomics. 1992. Vol. 14, № 4. Pp. 1104-1106. DOI: 10.1016/s0888-7543(05)80138-7.

VanNess S.H., Owens M.J., Kilts C.D. The variable number of tandem repeats element in DAT1 regulates in vitro dopamine transporter density // BMC Genet. 2005. Vol. 6. № 1. P. 55. DOI: 10.1186/1471-2156-6-55.

Winkler J.K., Woehning A., Schultz J.-H., Brune M., Beaton N., Challa T.D., Minkova S., Roeder E., Nawroth P.P., Friederich H.C., Wolfrum C., Rudofsky G. TaqIA polymorphism in dopamine D2 receptor gene complicates weight maintenance in younger obese patients // Nutrition. 2012. Vol. 28. № 10. Pp. 996-1001. DOI: 10.1016/j.nut.2011.12.018.

Vasileva, Aleksandra A., Vasilyev, Vasiliy A., Negasheva, Marina A.

\section{Gene polymorphism of the dopamine transporter and dopamine receptor D2 is associated with physique*}

DOI: $10.33876 / 2311-0546 / 2020-52-4 / 232-248$

One of the topical interdisciplinary areas of scientific research is the study of the mechanisms underlying the formation of the human constitution. The polymorphism of the neurotransmitter systems genes is quite often considered in connection with various aspects of the human psyche and physique. The aim of the present study is to search for the associations of the dopamine transporter and dopamine D2 receptor gene polymorphisms with physique and functional characteristics of the cardiovascular system. The anthropogenetic examination of 216 males and females aged 16-23 years was conducted in the Republic of Mordovia. The body length and weight, the waist and hips circumferences, the skinfolds thickness on the trunk and extremities were measured, while the systolic and diastolic blood pressure, heart rate were determined as the functional indicators of the cardiovascular system. All respondents were genotyped at the 
loci 3'-UTR VNTR DAT1 of the dopamine transporter and DRD2/ANKK1 Taq1A (rs1800497) of the second type dopamine receptor. Significant $(p<0.05)$ associations were found using the Mann-Whitney U-test (a comparative analysis of the average values) of morphofunctional indicators in people with different genotypes of the studied genes. Females with at least one allele 9 at the DAT1 are characterized by higher body weight and waist circumference compared with those with genotype 9-. Female carriers of the C/C genotype at the DRD2/ANKK1 Taq1A demonstrated higher indicators of body mass, body mass index, waist circumference, abdominal, triceps and thigh skinfolds, as well as a higher heart rate compared to other female genotypes. There were no significant differences in morphofunctional characteristics for males. The revealed associations of the polymorphism of the DAT1 and DRD2 with morphofunctional characteristics are probably due to the complex influence of genetic factors on the formation of body features. The results can be used in personalized medicine.

Key words: anthropometry; body mass index; fat deposition; youth of Mordovia; human genetics; DAT1; DRD2/ANKK1 Taq1A

* Vasileva Aleksandra A. - Lomonosov Moscow State University, Faculty of Biology, Department of Anthropology, (Leninskiye Gory, 1/12, Moscow). E-mail: vasileva@mail.bio.msu.ru

Vasilyev Vasiliy A. - Institute of Gene Biology RAS, Lab. of Genome Organization, (Vavilova 34/5, Moscow).E-mail: shunka@mail.ru

Negasheva Marina A. - Lomonosov Moscow State University, Faculty of Biology, Department of Anthropology, (Leninskiye Gory, 1/12, Moscow). E-mail: negasheva@mail.ru

The research was supported by the Russian Foundation for Basic Research (RFFI, project No. 18-0900290), Biological and social factors of microevolutionary changes in the morphofunctional status and level of sexual dimorphism in populations of the modern population" and the program "Postgenomic technologies and promising solutions in biomedicine"

\section{References}

Ariza, M., M. Garolera, M.A. Jurado, I. Garcia-Garcia, I. Hernan, C. Sánchez-Garre, M. VernetVernet, M.J. Sender-Palacios, I. Marques-Iturria, R. Pueyo, B. Segura, and A. Narberhaus. 2012. Dopamine Genes (DRD2/ANKK1-TaqA1 and DRD4-7R) and Executive Function: Their Interaction with Obesity. PLoS One 7 (7): e41482. https://doi.org/10.1371/journal.pone.0041482

Avsar, O., A. Kuskucu, S. Sancak, and E. Genc. 2017. Are dopaminergic genotypes risk factors for eating behavior and obesity in adults? Neurosci. Let. 654: 28-32. https://doi.org/10.1016/j. neulet.2017.06.023

Benton, D., and H.A. Young. 2016. A meta-analysis of the relationship between brain dopamine receptors and obesity: a matter of changes in behavior rather than food addiction? Int. J. Obes. 40 (1): S12-S21. https://doi.org/10.1038/ijo.2016.9

Bieliński, M., M. Jaracz, N. Lesiewska, M. Tomaszewska, M. Sikora, R. Junik, A. Kamińska, A. Tretyn, and A. Borkowska. 2017. Association between COMT Val158Met and DAT1 polymorphisms and depressive symptoms in the obese population. Neuropsychiatr. Dis. Treat. 13: 2221-2229. https://doi.org/10.2147/NDT.S138565

Bondareva, E.A., M.A. Negasheva, A.V. Grudieva, and T.V. Tarasova. 2016. Assotsiatsii T/A-polimorfizma gena FTO s kharakterom zhirootlozheniia u iunoshei i devushek [T/A-polymorphism of the FTO gene is associated with fat accumulation traits in youngsters]. Vestnik Moskovskogo Universiteta. Seria XXIII. Antropologia 4: 69-77.

Butovskaya, P.R., M.L. Butovskaya, V.A. Vasilyev, O.E. Lazebny, D.V. Shibalev, E.V. Veselovskaya, I.G. Udina, and A.P. Ryskov. 2013. Molecular-genetic polymorphisms of dopamine, serotonin and androgenic systems as molecular markers of success in judo wrestling sportsmen. $J$. Bioanal. Biomed. S3: 005. https://doi.org/10.4172/1948-593X.S3-005

Costa, A., M. Riedel, U. Müller, H.J. Möller, and U. Ettinger. 2011. Relationship between SLC6A3 gen- 
otype and striatal dopamine transporter availability: A meta-analysis of human single photon emission computed tomography studies. Synapse 65 (10): 998-1005. https://doi.org/10.1002/syn.20927

Davis, C., K. Patte, R. Levitan, C. Reid, S. Tweed, and C. Curtis. 2007. From motivation to behaviour: a model of reward sensitivity, overeating, and food preferences in the risk profile for obesity. Appetite 48 (1): 12-19. https://doi.org/10.1016/j.appet.2006.05.016

Davis, C., R.D. Levitan, Z. Yilmaz, A.S. Kaplan, J.C. Carter, and J.L. Kennedy. 2012. Binge eating disorder and the dopamine D2 receptor: genotypes and sub-phenotypes. Prog. Neuropsychopharmacol. Biol. Psychiatry 38 (2): 328-335. https://doi.org/10.1016/j.pnpbp.2012.05.002

Doehring, A., N. Hentig, J. Graff, S. Salamat, M. Schmidt, G. Geisslinger, S. Harder, and J. Lotsch. 2009. Genetic variants altering dopamine D2 receptor expression or function modulate the risk of opiate addiction and the dosage requirements of methadone substitution. Pharmacogenet. Genomics 19 (6): 407-414. https://doi.org/10.1097/FPC.0b013e328320a3fd

Eubanks, J.H., M. Djabali, L. Selleri, D.K. Grandy, O. Civelli, D.L. McElligott, and G.A.Evans. 1992. Structure and linkage of the D2 dopamine receptor and neural cell adhesion molecule genes on human chromosome 11q23. Genomics 14 (4): 1010-1018. https://doi.org/10.1016/s0888-7543(05)80124-7

Flegontova, O.V., A.V. Khrunin, O.I. Lylova, L.A. Tarskaia, V.A. Spitsyn, A.I. Mikulich, and S.A. Limborska. 2009. Haplotype frequencies at the DRD2 locus in populations of the East European Plain. BMC Genet. 10: 62. https://doi.org/10.1186/1471-2156-10-62

Giros, B., and M.G. Caron. 1993. Molecular characterization of the dopamine transporter. Trends Pharmacol. Sci. 14 (2): 43-49. https://doi.org/10.1016/0165-6147(93)90029-j

Hu, Y., J. Hakkola, M. Oscarson, M. Ingelman-Sundberg. 1999. Structural and Functional Characterization of the 5'-flanking Region of the Rat and Human Cytochrome P450 2E1 Genes: Identification of a Polymorphic Repeat in the Human Gene. Biochem. Biophys. Res. Commun. 263 (2): 286-293. https://doi.org/10.1006/bbrc.1999.1362

Kalmin, O.V., Yu.S. Afanasievskaia, and A.V. Samotuga. 2010. Otsenka osobennostei antropometricheskikh parametrov raspredeleniia somatotipov lits iunosheskogo vozrasta goroda Krasnodara i Krasnodarskogo Kraia [Assessment of the characteristics of the anthropometric parameters of the distribution of somatotypes of young people of Krasnodar and the Krasnodar Territory]. Izvestiia vysshikh uchebnykh zavedenii. Povolzhskii region. Meditsinskie nauki 1 (13): 3-11.

Kolokoltsev, M.M., and V.Yu. Lebedinsky. 2012. Sravnitel'naia kharakteristika urovnia fizicheskogo razvitiia studencheskoi molodezhi iunosheskogo vozrasta Irkutskoi oblasti [Comparative characteristics of level of physical development of young students of Irkutsk]. Biulleten' VSNC SO RAMN 6 (88): 47-54.

Krause, J., S.H. Dresel, K.H. Krause, C. La Fougère, P. Zill, and M. Ackenheil. 2006. Striatal dopamine transporter availability and DAT -1 gene in adults with ADHD: no higher DAT availability in patients with homozygosity for the 10-repeat allele. World J. Biol. Psychiatry 7 (3): 152-157. https://doi.org/10.1080/15622970500518444

Negasheva, M.A. 2017. Osnovy antropometrii [Basics of Anthropometry]. Moscow: Ekon-Inform. Nymberg, C., T. Banaschewski, A.L. Bokde, C. Büchel, P. Conrod, H. Flor, V. Frouin, H. Garavan, P. Gowland, A. Heinz, B. Ittermann, K. Mann, J.L. Martinot, F. Nees, T. Paus, Z. Pausova, M. Rietschel, T.W. Robbins, M.N. Smolka, A. Ströhle, G. Schumann, and T. Klingberg. 2014. DRD2/ANKK1 polymorphism modulates the effect of ventral striatal activation on working memory performance. Neuropsychopharmacology 39 (10): 2357-2365. https://doi.org/10.1038/npp.2014.83

Palmeira, L., M.Cunha, C. Padez, M. Alvarez, J. Pinto-Gouveia, and L. Manco. 2019. Association study of variants in genes FTO, SLC6A4, DRD2, BDNF and GHRL with binge eating disorder (BED) in Portuguese women. Psychiatry Res. 273: 309-311. https://doi.org/10.1016/j. psychres.2019.01.047

Rand, C.M., P.P. Patwari, E.A. Rodikova, L. Zhou, E.M. Berry-Kravis, R.J. Wilson, T. BechHansen, and D.E. Weese-Mayer. 2011. Rapid-onset obesity with hypothalamic dysfunction, hypoventilation, and autonomic dysregulation: analysis of hypothalamic and autonomic candidate genes. Pediatr. Res. 70 (4):375-378. https://doi.org/10.1203/PDR.0b013e318229474d

Rivera-Iñiguez, I., A. Panduro, O. Ramos-Lopez, S.J. Villaseñor-Bayardo, and S. Roman. 2019. 
DRD2/ANKK1 TaqI A1 polymorphism associates with overconsumption of unhealthy foods and biochemical abnormalities in a Mexican population. Eat. Weight. Disord. 24 (5): 835-844. https://doi.org/10.1007/s40519-018-0596-9

Savitz, J., C.A. Hodgkinson, C. Martin-Soelch, P.H. Shen, J. Szczepanik, A.C. Nugent, P. Herscovitch, A.A. Grace, D. Goldman, and W.C. Drevets. 2013. DRD2/ANKK1 Taq1A polymorphism (rs1800497) has opposing effects on D2/3 receptor binding in healthy controls and patients with major depressive disorder. Int. J. Neuropsychopharmacol. 16 (9): 2095-2101. https://doi.org/10.1017/S146114571300045X

Sikora, M., A. Gese, R. Czypicki, M. Gąsior, A. Tretyn, J. Chojnowski, M. Bieliński, M. Jaracz, A. Kamińska, R. Junik, and A. Borkowska. 2013. Correlations between polymorphisms in genes coding elements of dopaminergic pathways and body mass index in overweight and obese women. Endokrynol. Pol. 64 (2): 101-107.

Sineva, I.M., M.A. Negasheva, and Yu.M. Popov. 2017. Sravnitel'nyi analiz urovnia fizicheskogo razvitiia studentov raznykh gorodov Rossii [Comparative analysis of physical development of students from different cities of Russia]. Vestnik Moskovskogo Universiteta. Seria XXIII. Antropologia 4: 17-27.

Smith, C.T., L.C. Dang, J.W. Buckholtz, A.M. Tetreault, R.L. Cowan, R.M. Kessler, and D.H. Zald. 2017. The impact of common dopamine D2 receptor gene polymorphisms on D2/3 receptor availability: C957T as a key determinant in putamen and ventral striatum. Transl. Psychiatry 7 (4): e1091. https://doi.org/0.1038/tp.2017.45

Stice, E., K.S. Burger, and S. Yokum. 2015. Reward Region Responsivity Predicts Future Weight Gain and Moderating Effects of the TaqIA Allele. J. Neurosci. 35 (28): 10316-10324. https:// doi.org/10.1523/JNEUROSCI.3607-14.2015

Stice, E., S. Spoor, C. Bohon, and D.M. Small. 2008. Relation between obesity and blunted striatal response to food is moderated by TaqIA A1 allele. Science 322 (5900): 449-452. https://doi. org/10.1126/science. 1161550

Uzun, M., E. Saglar, S. Kucukyildirim, B. Erdem, H. Unlu, and H. Mergen. 2015. Association of VNTR polymorphisms in DRD4, 5-HTT and DAT1 genes with obesity. Arch. Physiol. Biochem. 121 (2): 75-79. https://doi.org/10.3109/13813455.2014.985686

Van Dyck, C.H., R.T. Malison, L.K. Jacobsen, J.P. Seibyl, J.K. Staley, M. Laruelle, R.M. Baldwin, R.B. Innis, and J. Gelernter. 2005. Increased dopamine transporter availability associated with the 9-repeat allele of the SLC6A3 gene. J. Nucl. Med. 46 (5): 745-751.

Vandenbergh, D.J., A.M. Persico, A.L. Hawkins, C.A. Griffin, X. Li, E.W. Jabs, and G.R. Uhl. 1992. Human dopamine transporter gene (DAT1) maps to chromosome 5p15. 3 and displays a VNTR. Genomics 14 (4): 1104-1106. https://doi.org/10.1016/s0888-7543(05)80138-7

VanNess, S.H., M.J. Owens, and C.D. Kilts. 2005. The variable number of tandem repeats element in DAT1 regulates in vitro dopamine transporter density. BMC Genet. 6 (1): 55. https://doi. org/10.1186/1471-2156-6-55

Viazova, L.S., and A.V. Solntseva. 2018. Vzaimnoe vliianie geneticheskogo polimorfizma TaqIA gena dofaminovogo retseptora 2 tipa, urovnei dofamina i leptina krovi na formirovanii raznykh form ozhireniia u detei [Mutual effect of TaqIA genetic polymorphism of the dopamine receptor type 2 gene, levels of dopamine and blood leptin on the formation of various forms of obesity in children]. Detskaia meditsina Severo-Zapada 7 (1):71.

Winkler, J.K., A. Woehning, J.-H. Schultz, M. Brune, N. Beaton, T.D. Challa, S. Minkova, E. Roeder, P.P. Nawroth, H.C. Friederich, C. Wolfrum, and G. Rudofsky. 2012. TaqIA polymorphism in dopamine D2 receptor gene complicates weight maintenance in younger obese patients. $\mathrm{Nu}$ trition 28 (10): 996-1001. https://doi.org/10.1016/j.nut.2011.12.018 
(С) А.И. Бураев

\title{
ПАМЯТИ УЧИТЕЛЯ. АНТРОПОЛОГИЧЕСКИЕ ИССЛЕДОВАНИЯ ЦИРКУМБАЙКАЛЬЯ В ТРУДАХ И.И. ГОХМАНА*
}

\begin{abstract}
Статья посвящена памяти выдающегося советского и российского антрополога Ильи Иосифовича Гохмана. Констатирован широкий круг научных интересов исследователя. В сообщении рассмотрен региональньй аспект деятельности ученого. Проанализировань работы И.И. Гохмана по антропологии населения Прибайкалья и Забайкалья. Ученый внес значительный вклад в изучение краниологии эпохи неолита, основываясь на материалах Фофановского могильника из Забайкалья. И.И. Гохман дал полную антропологическую характеристику и историческую интерпретацию краниологических данных по населению культуры плиточных могил бронзового века. Вылеляются исследования им населения эпохи хунну, в которых была впервые зафиксирована европеоидная примесь у древнего населения Байкальской Сибири, впоследствии подтвержденная в совместной фундаментальной монографии В.П. Алексеева и И.И. Гохмана. В статье проанализировань работы И.И. Гохмана по антропологическим материалам средневековых могильников Улан-Бор и Усть-Талькин в Прибайкалье. Особое место занимает концепџия И.И. Гохмана о формировании цчентральноазиатской расы в результате метисации байкальской расы с европеоидами. Отдельно упомянута выдающаяся работа И.И. Гохмана «Происхождение иентральноазиатской расы в свете новых палеоантропологических материалов». В ней ученым были введены новые краниологические индексы, дан новаторский анализ материала, изложена новая теоретическая концепџия. И.И. Гохман ввел в научный оборот новые уникальные краниологические материаль, предложил новые теоретические разработки, в корне изменившие представления об антропологических прочессах на территории Прибайкалья и Забайкалья. Работь И.И. Гохмана вызвали плодотворную дискуссию среди специалистов и дали импульс новым исследованиям по антропологии Байкальской Сибири.
\end{abstract}

Ключевые слова: антропология, краниология, центральноазиатская раса, Байкальская Сибирь, Прибайкалье, Забайкалье

Выдающийся советский и российский антрополог Илья Иосифович Гохман был не только научным руководителем, но и Учителем с большой буквы для автора настоящей статьи. Разумеется, у него было много учеников, но мне выпала честь быть одним из последних.

Бураев Алексей Игнатьевич - к.и.н., научный сотрудник Отдела истории и культуры Центральной Азии, Институт монголоведения, буддологии и тибетологии Сибирского отделения РАН. (670047, Улан-Удэ, ул. Сахьяновой, 6. Россия). Эл. почта: buraev 1961@mail.ru

* Статья подготовлена в рамках государственного задания (проект XII.191.1.2). Межкультурное взаимодействие, этнические и социально-политические процессы в Центральной Азии, № AAАA-A17-117021310264-4 (Intercultural relationships, ethnic and sociopolitical processes in Central Asia) 